УДК 338.48:378

DOI: $\underline{10.35619 / \text { iiu.v1i13.340 }}$

Савчук Борис

доктор історичних наук, професор, професор кафедри педагогіки імені Богдана Ступарика Прикарпатського національного університету імені Василя Стефаника, м. Івано-Франківськ, Україна ORCID: 0000-0003-2256-0845 e-mail: boris_savchuk@ukr.net

Шевчук Христина студентка другого (магістерського) рівня освіти кафедри педагогіки імені Богдана Ступарика Прикарпатського національного університету імені Василя Стефаника, м. Івано-Франківськ, Україна ORCID: 0000-0002-0034 5143 e-mail: roshniv.ch@gmail.com

\title{
ПОНЯТТЯ «ЕКОЛОГІЧНА КУЛЬТУРА», «ЕКОЛОГІЯ КУЛЬТУРИ», «ЕКОЛОГІЯ КУЛЬТУРНА» КРІЗЬ ПРИЗМУ ПОСТРАДЯНСЬКОГО ТЕРМІНОЛОГІЧНОГО ДИСКУРСУ
}

Анотація. У статті представлено результати синтезованого аналізу генези та сутності понять «екологічна культура», «екологія культури», «екологія культурна». Крізь призму пострадянського наукового дискурсу розглядаються визначення їхніх дефінітивних контурів i сутніснозмістового наповнення. Пропонуються підходи до інтерпретації цих термінів та їхнього використання в наукових дослідженнях.

Доведено, що в радянській та сучасній російській науці утвердилася позиція, згідно якої запровадження в науковий обіг понять «екологічна культура», «екологія культури» пов'язується з іменем відомого філолога і культуролога Д. Лихачова. Представлена позиція сучасних українських науковців, відповідно до якої походження терміна «екологічна культура» ототожнюється з працями представників американської школи культурної екології, що існувала у 20-ті рр. ХХ ст. Доводиться авторська позиція, відповідно до якої термін «культурна екологія» («cultural ecology») увів до наукового обігу 1955 р. американський антрополог Дж. Стюард. Здійснено порівняння поглядів і тлумачень цих понять у працях Д. Лихачова i Дж. Стюарда.

На основі аналізу масиву тематичних репрезентативних студій визначено спільні та відмінні підходи до використання і трактування термінів «екологічна культура», «екологія культури», «екологія культурна» у різних галузях знань, в предметно-тематичних науковопедагогічних дослідженнях, у сучасній українській і російській науці та англомовному науковому просторі.

(C) Савчук Б., Шевчук Х., 202150 


\section{Інноватика у вихованні. Випуск 13.Том 1. 2021.}

Обгрунтовано, що пріоритетний освітній вектор зумовив найбільш предметне вивчення феномену екологічної культури в царині педагогіки, реконструйовано архітектоніку його рецепції в педагогічній науці України.

Ключові слова: методологія педагогічної науки, науковопедагогічний дискурс, поняттєво-категорійний апарат, екологічна культура, екологія культури, екологія культурна.

Постановка проблеми. Поняттєво-категорійний апарат, як важливий компонент методології кожної галузі знань становить «альфу і омегу» проведення фундаментальних та прикладних досліджень. Від правильного вибору і розуміння понять, термінів, категорій, якими оперує автор, залежить загальний науково-теоретичний рівень його дослідження та об'єктивність, обгрунтованість запропонованих положень, висновків та експериментальних результатів. Для української педагогічної науки ця проблема набуває особливої гостроти й актуальності, адже ії терміносистема перебуває у стадії становлення. Вона має міждисциплінарний характер, розвивається під впливом запозичень 3 євроатлантичного i пострадянського освітньо-наукового простору та національного наукового дискурсу. Дається взнаки «термінологічна спадщина» радянського періоду, окремі компоненти якої не втратили своєї наукової вартості, тож творчо адаптуються до нових реалій.

Означені й інші чинники зумовлюють актуальність і практичну сутність заявленої в назві статті проблеми. Загострення екологічної кризи на глобальному рівні і природоохоронної ситуації в Україні та складні суперечливі трансформації сучасного культурного життя суспільства i внутрішнього духовного світу кожної людини активізують увагу представників різних галузей знань до осмислення широкого кола проблем екології та культури. Це зумовило активне оперування поняттями «екологічна культура», «екологія культури», «екологія культурна» та ін., пов'язаними з ними термінами. Як наслідок, через свою сутнісно-змістову «поліфонію», наукові традиції, недостатній рівень методологічної культури в наукових студіях вони часто вживаються довільно, як синонімічні (взаємозамінні) або ж у значеннях, які не відповідають дійсному змісту. Це викликало потребу їхнього предметного дефінітивного аналізу крізь призму пострадянського міждисциплінарного наукового дискурсу.

Аналіз останніх досліджень 3 проблеми. Порушена проблема знайшла предметне відображення в дослідженнях з теорії і практики розвитку екологічної культури (Г. Васюкова, О. Грошева, С. Дерябо, А. Захлєбний, О. Пруцакова, Г. Пустовіт, С. Совгіра, М. Шаповал, Н. Ясінська та ін.) та екології культури (Дж. Голден, І. Лисаковський, Д. Лихачов, Дж. Стюард, О. Устюгова та ін.). Дотично вона розглядається в студіях 3 розвитку екологічної освіти і екологічного виховання особистості (Н. Авраменко, П. Бачинський, І. Звєрєв, В. Крисаченко, О. Мітрясова, Н. Пустовіт, В. Танська та ін.). Предметом критичного 


\section{Інноватика у вихованні. Випуск 13.Том 1. 2021.}

аналізу стали дослідження, що стосуються формування терміносистеми екологічної культури (О. Дорошко, Л. Курняк, В. Лещинська, А. Льовочкіна, Л. Мухаменшина, С. Совгіра, О. Устюгова та ін.). Отож нагромадження значного масиву різнопрофільної літератури, у якій автори оперують означеними поняттями, та розмаїття, суперечливість їхніх трактувань і контекстних інтерпретацій зумовили потребу предметного аналізу зазначених дефініцій у контексті сучасного наукового дискурсу.

Мета дослідження - синтезований аналіз генези та сутності понять «екологічна культура», «екологія культури», «екологія культурна» задля визначення їхніх дефінітивних контурів і сутнісно-змістового наповнення та адекватної інтерпретації й використання в наукових дослідженнях.

Виклад основного матеріалу дослідження. Зважаючи на багатогранність і поліструктурованість категорій «екологічна культура», «екологія культури», «екологія культурна», 3 одного боку, та їхній сутнісно-змістовий «дуалізм», розмитість і невиразність, 3 іншого, вони потребують синтезованого осмислення в проєкціях міждисциплінарності, ретроспективи та в інших проблемних і змістових ракурсах. Для цього варто передусім з'ясувати їхнє походження та детермінанти подальших трансформацій.

У радянській та сучасній російській науці утвердилася позиція (Дорошко, 2012; Лихачёв, 2017; Мухамедишина, 2012 та ін.), що також має місце i в українському гуманітарному дискурсі, згідно 3 якою запровадження в науковий обіг понять «екологічна культура», «екологія культури» пов'язується з іменем знаного вченого, філолога і культуролога Д. Лихачова. У своїй однойменній праці він представив доволі інноваційну для радянської науки рецепцію екології культури та порушив питання про нагромадження не лише краєзнавчих, а й грунтовних науково-теоретичних знань для її перетворення в окрему дисципліну (Лихачёв, 1984).

При цьому, що принципово важливо для нашого дослідження, науковці абстрагуються від того факту, Д. Лихачов уживав словосполучення «екологія культури». Унаслідок словотвору воно трансформувалося в поняття «екологічна культура». У науковому вжитку ці два феномени стали синонімізуватися (ототожнюватися), хоча насправді відображають різні науково-дисциплінарні напрями.

Про означену ситуацію свідчать репрезентативні російські академічні видання та наукові студії. Етимологія поняття «екологія культури» у них виводиться 3 давньогрецького «Oikos» («будинок», «житло», «місцеперебування»). У міждисциплінарному аспекті воно пов'язується із соціальною екологією, яка на перетині природничих, суспільних, технічних наук фокусує на розв'язанні проблем у системі «суспільствоприрода». Домінуюча рецепція розгляду цієї дефініції в ракурсі екології людини і культурології акцентує на трьох основних аспектах їі розуміннях. Перший стосується ідеї рівноважного зв'язку людини та природи в їхньому естетичному й художньо-практичному переломленні. Другий аспект відповідає концепту Д. Лихачова, зокрема, стосується збереження 


\section{Інноватика у вихованні. Випуск 13.Том 1. 2021.}

історичної, духовної, матеріально-художньої спадщини культурного середовища, що природно необхідне людині для їі соціальної і моральної життєдіяльності. Третій аспект визначає загальний підхід розвитку сучасного мистецтва, що спирається на ідеї єдності та гармонії людини, природи, культури. Він акцентує на ідеї «олюднення» природи завдяки наближенню, поверненню до неї людини (Лисаковский, 2002, с. 206).

В українському міждисциплінарному науковому полі поширена позиція, згідно з якою походження терміна «екологічна культура» узгоджується з працями представників американської школи культурної екологї, яка існувала у 20-ті pp. ХХ ст. Щоправда, автори навіть у спеціальних науково-теоретичних працях з цієї проблеми (Курняк, 2015; Льовочкіна, 2013 та ін.), ретранслюючи це твердження, не вказують конкретних джерел, а також прізвищ і праць науковців.

Для прояснення ситуації, що склалася в пострадянській українській та російській науці, апелюємо до англомовного наукового простору. Перекладна лінгвістика свідчить, що кожне 3 досліджуваних понять має такі англо-, україно- і російськомовні відповідники: «еcological culture» «екологічна культура» - «экологическая культура»; «cultural ecology» i «ecology of culture» - «екологія культури» - «экология культуры».

Аналізовані нами терміни мають різне сутнісно-змістове наповнення. Перш ніж перейти до предметного дефінітивного аналізу, прояснимо ситуацію щодо їхнього походження. Важливий ключ для цього дає, на жаль, недостатньо представлений в українській гуманітаристиці, зокрема, педагогічному дискурсі, наратив західної науки, згідно з яким термін «cultural ecology» («екологія культури») увів відомий американський антрополог Дж. Стюард (Julian Steward) у праці «Теорія культурних змін: методологія полілінійної еволюції» (Theory of Culture Change: The Methodology of Multilinear Evolution, 1955). Культурна екологія в ній визначається як методологія вивчення проблеми адаптації людини до розмаїття довкілля. На думку вченого, культурна екологія має вивчати зміни, що відбуваються в оточуючому середовищі під впливом адаптації людини до його умов. Сутність теорії полягає в тому, що будь-яка конкретна людська адаптація була «історично зумовлена», тож вона несла знання, технології, практику, які давали змогу людині жити у своєму середовищі й адаптувати («окультурювати») його до своїх потреб (Steward, 1955).

Аналіз репрезентативних студій (Holden, 2015) засвідчив, що в англомовному (американському) науковому полі переважно фігурує термін «cultural ecology» у його стюардському розумінні. Фактично як синонімічне йому (але зрідка, переважно при обстеженні залишків старовини) використовується поняття «есology of culture».

Попри сумнозвісну «залізну завісу», якою тоталітарний режим СРСР відгородив радянську науку від «згубного впливу Заходу», зі всього видно, що Д. Лихачов був грунтовно ознайомлений з ідеями Дж. Стюарда. Треба віддати належне вченому, який спромігся адаптувати стюардські 


\section{Інноватика у вихованні. Випуск 13.Том 1. 2021.}

постулати в радянський науковий простір, надавши їм відповідного, подекуди пафосного, патріотичного i мораль-етичного забарвлення. Рецепції цих двох учених мають спільний стрижень - середовищний підхід до проблем культури та екології. В інтерпретації Д. Лихачова він виглядає так: екологію не можна обмежувати тільки завданнями збереження природного біологічного середовища, бо для життя людини не менш важливе середовище, створене культурою його предків та іiі власними зусиллями. Збереження культурного середовища - завдання не менш істотне, аніж збереження довкілля. Якщо природа необхідна людині для їі біологічного життя, то культурне середовище настільки ж важливе для їі духовності, моральної самодисципліни, соціалізації. Тому, одночасно 3 вивченням різних видів культури і залишків культурного минулого та реставрації і збереження пам'яток, варто активно вивчати вплив на людину природного та культурного середовищ у всіх їхніх взаємозв'язках (Лихачов, 1984).

Вивчення масиву репрезентативних студій на предмет використання $\mathrm{i}$ трактування трьох досліджуваних термінів виявило доволі складну ситуацію, що нагадує «лабіринт». Орієнтири виходу з нього визначаємо трьома положеннями. Перше: у пострадянській українській та російській гуманітаристиці існує доволі чітке розуміння сутності понять «екологічна культура» та «екологія культури» / «екологія культурна», однак вони повсякчас використовуються як синонімічні, що позначається на якості наукових наративів. Друге: в українському науковому просторі поняття «екологія культурна» вживається переважно у словниковій літературі (Енциклопедія Сучасної України, 2009 та ін.), за своїм змістом воно фактично відповідає поняттю «екологія культури» та його англомовному відповіднику «cultural ecology». Третє: російськомовне поняття «экология культуры» використовується в тому ж значенні (є відповідником) україномовному поняттю «екологія культури» (поняття «екологія культурна» в російськомовному перекладі («экологическая культура») не має змісту).

Як випливає з репрезентативних наукових студій (Генисаретский, 1991; Енциклопедія Сучасної України, 2009; Устюгова, 2013 та ін.), у сучасному українському та російському дискурсі в поняття «екологія культури» («екологія культурна») та «экология культуры» вкладається, якщо не тотожний, то доволі подібний зміст, який дедалі більше віддаляється від «первісного» стюардського трактування. Формально (інституційно) воно отримало дисциплінарний статус і позначає один iз розділів культурології - екологію культури. Завдяки розширенню змістовно-тематичного поля феномен екології культури набув міждисциплінарного характеру, тому найбільш доречним вважаємо галузевий підхід до його розуміння. Його екологічний стрижень фокусує (проєктує) на різні сфери культурного буття. Це формалізується i номінується у відповідних галузях суспільних відносин та наукових знань: етноекологія; «екологія історії»; «екологія мови»; «екологічна естетика»; 


\section{Інноватика у вихованні. Випуск 13.Том 1. 2021.}

«еко-культура» і т. п. Крізь призму цих наукових напрямів (субдисциплін) розглядається широкий спектр культурологічних проблем, що, приміром, стосуються співвідношення високої та масової культури; окремого культурного «Я» та всього «культурного контенту» і т. ін.

Переходячи до з'ясування ще одного стрижневого для нашого дослідження поняття «екологічна культура», передусім з'ясуємо причини того, що в науково-педагогічному дискурсі побутує ситуація, коли як синонімічне («взаємозамінне») йому вживається поняття «екологія культури».

Одну 3 таких причин убачаємо в подібності фонетики, що накладається на домінуючу тенденцію отримання наукової інформації 3 мережі Інтернету. Запит у пошуковій системі Google на одне з цих понять дає фактично однакові результати - переважно з'являються інформативні матеріали, пов'язані $з$ екологічною культурою. Побіжне ознайомлення 3 півсотнею такого зразка документів, що стосуються освіти, навчання i виховання, громадської активності тощо, свідчить, що в інформативнотехнологічному просторі домінує поняття «екологічна культура». Поняття «екологія культури» у більшості (чотирьох із п'яти) випадків вживається як його «замінник», а в означеному вище власному сутнісному значенні в одному $з$ п’яти випадків.

Друга причина міститься в домінуванні «монодисциплінарного» підходу, коли, до прикладу, у процесі вивчення екологічної культури у сфері педагогіки і освіти дослідники абстрагуються від наукового доробку про цей феномен у філософії, культурології, психології, екології, соціології, педагогіки, інших галузях знань. Їхні концептуальні напрацювання у синтезований міждисциплінарній проєкції дають розуміння екологічної культури як напряму людської діяльності та мислення, від якого залежать природне існування i сталий розвиток сучасної цивілізації та життєдіяльність, завдяки якій досягається взаємна адаптація довкілля та людини. Саме $з$ таких позицій вивчається широке коло питань щодо використання i перетворення природи людиною, наслідків цієї діяльності та взаємовпливів соціального і природного в житті людини тощо.

Пріоритетний освітній вектор зумовив активне вивчення екологічної культури педагогічною наукою. Архітектоніку iii рецепції можна представити у такий спосіб. Відправним аспектом іï вивчення $\epsilon$ ракурс інтеграції України у світовий культурний простір. Він посилювався з кінця XX ст. і став базовим у контексті реалізації доктрини сталого розвитку. 3 таких позицій предметно аналізуються ухвали самітів ООН в Ріо-деЖанейро «Порядок денний на ХХІ століття» (1992), Йоганнесбурзі (2002), Всесвітньої конференції ЮНЕСКО в Японії та ін. Вони позначають етапи формування концепції сталого розвитку як нової парадигми світового порядку, що акцентує на необхідності постійної взаємодії людини 3 природним середовищем 3 урахуванням законів природної регуляції. Згідно з виробленою ними концептуальною стратегією, саме освіта має 


\section{Інноватика у вихованні. Випуск 13.Том 1. 2021.}

стати головним механізмом забезпечення сталого розвитку природи i суспільства та виховання екологічно відповідальної особистості, яка усвідомлює цілісність природи та суспільства як фундаментально рівних складників єдиного цілого. Міжнародні акти стали орієнтирами розробки концептуальних засад екологічної освіти України (Концепція, 2002).

Другим усталеним компонентом науково-педагогічної рецепції екологічної культури стало з'ясування їі сутності та багатогранності в ретроспективі розвитку суспільної та педагогічної думки. У цьому руслі акцентується на мислителях Античності та західних і вітчизняних культурологічних концептах кінця XVIII - XIX ст. (А. Дістервег, Я. Коменський, І. Песталоцці, Ж.-Ж. Руссо та ін.) і ХХ ст. (В. Вернадський, В. Сухомлинський та ін.). 3 прив'язкою до цих та інших чинників розробляються періодизації розвитку екологічної культури та екологічної освіти і виховання.

Третім найбільш складним i контроверсійним компонентом $\epsilon$ розробка науково-теоретичних засад екологічної культури. Це знайшло відображення в різних сутнісно-змістових характеристиках та численних визначеннях класифікаціях, типологіях, моделях, інтерпретаціях основних компонентів i аспектів цього феномену. У такому аспекті осмислюється четвертий компонент у вигляді зарубіжного досвіду розвитку екологічної культури, зокрема, у контексті його впровадження в український освітній процес та порівняння (спільне і особливе) 3 відповідним вітчизняним досвідом. П'ятий базовий компонент становить проблематика з визначення і розробки педагогічних умов та педагогічного супроводу формування екологічної культури (методи, технології, форми, засоби, навчально-методичне забезпечення тощо) у різних типах освітніх закладів.

У такому процесі поряд 3 екологічною культурою розробляється $\mathrm{i}$ тестується широкий перелік взаємопов'язаних, супутніх та супідрядних понять і термінів: «екологічний підхід», «екологічна освіта», «екологічна підготовка [майбутніх фахівців]», «екологічна компетентність», «екологічні знання», «екологічне виховання», «екологічне навчання», «екологічна поведінка», «екологічне проєктування», «екологізація виховання / навчання», «екологічна свідомість», «екологічна особистість» та ін. Їхній предметний термінологічний аналіз показав, що, поряд зі спільними, суголосними позиціями, науковці пропонували їхні різні, відмінні інтерпретації, які нерідко суперечать одна одній, дублюють змістову сутність, функціональність, інші характеристики досліджуваних термінів.

Аналіз наукових джерел засвідчив, що через інертність мислення $\mathrm{i}$ звичку орієнтуватися на запропоновані попередниками теоретичні конструкти в сучасному науково-педагогічному дискурсі домінує доволі трафаретний інтеграл вивчення екологічної культури. Домінує «однолінійний» підхід, що проявляється у фокусуванні на їі одному 


\section{Інноватика у вихованні. Випуск 13.Том 1. 2021.}

компоненті - культурі та абстрагуванні від другого компонента - екології. Це апріорі порушує синкретизм цього двочленного (бінарного) феномену.

Обстоюємо підхід, згідно 3 яким екологічна культура має дефініціюватися на основі органічного синтезу двох означених компонентів. 3-поміж безлічі (близько 500) визначень феномену культури доцільно акцентувати на його первісному сенсі - обробіток, плекання (від лат. agricultura), яке давньоримський мислитель Цицерон ще у I ст. до н.е. використав щодо людини в значенні виховання, навчання. У такому контексті треба шукати точки дотику i переплетення 3 поняттям «екологія», яке 1866 р. увів у науковий обіг німецький вчений Е. Гекель для позначення наукового напряму з вивчення взаємин рослин і тварин із довколишнім середовищем. У $70-80-$ х рр. ХХ ст. у зв'язку із посиленням деградації і руйнування середовища життєдіяльності людини зміст поняття «екологія» трансформувався у такий спосіб, що замість різновидів рослинного і тваринного світу поставили людське суспільство. Відтак у сучасній науці стала переважати тенденція, згідно 3 якою наука екологія має розв'язувати не стільки біологічні, скільки соціальні проблеми. У такому сенсі вона стала позначати спосіб життя і певний зріз світобачення людства (Васюкова та Грошева, 2009).

Спеціальні аналітичні розвідки (Дорошко, 2012; Крисаченко, 1996; Лещинская, 2014; Льовочкіна, 2013; Мухамедишина, 2012 та ін.), згідно 3 нашим аналізом, артикулюють близько 60 визначень поняття «екологічна культура». Це засвідчує широкий міждисциплінарний інтерес до вивчення цього феномену та активний пошук його сприйнятливих інтерпретацій. Утім, навіть у галузевих ракурсах філософії, психології, культурології, педагогіки та ін. не відстежуємо консенсусних точок дотику, тож цей дискурс протікає безсистемно, хаотично. Як наслідок, розмаїття трактувань i плюралізм думок, підходів проявляється в еклектиці рефлексій екологічної культури, що не наближає до іiі цілісного структурованого осмислення.

Висновки і перспективи подальших розвідок формулюємо в одному блоці у таких положеннях:

1. Пострадянська гуманітаристика потребує «корекції» погляду, згідно з яким термін «екологія культури» був запроваджений до наукового обігу Д. Лихачовим.

2. С підстави вважати, що термін «екологічна культура» з'явився внаслідок трансформації терміна «екологія культури» («cultural ecology»). Це актуалізує потребу спеціального вивчення цього питання задля з'ясування того, коли, за яких обставин і т. ін. з'явився термін «екологічна культура».

3. У науковому, зокрема педагогічному дискурсі, варто чітко відмежовувати означені поняття як такі, що, попри фонетичну і деяку змістову близькість, все-таки позначають різні суспільні процеси і явища.

4. У процесі всебічного вивчення екологічної культури (iї дефініціювання, розробки науково-теоретичних засад, методик 


\section{Інноватика у вихованні. Випуск 13.Том 1. 2021.}

формування тощо) доцільно відходити від подекуди домінуючого (часто об'єктивованого, фатального) протиставлення людини і суспільства та природи, а натомість опиратися на постулат їхнього гармонійного співіснування, взаємодії. Попри всю складність і неоднозначність проблеми співвідношення природи та культури, вони мають розглядати в діалектичній єдності.

\section{СПИСОК ВИКОРИСТАНИХ ДЖЕРЕЛ}

Васюкова, Г. та Грошева, О. (2009). Екологія: підручник. К.: Кондор. $524 \mathrm{c}$.

Генисаретский, О. (1991). Экология культуры. Теоретические и проектные проблемы. М. 153 с.

Дорошко, О. (2012). Современные подходы к определению понятия «экологическая культура». Современные исследования социальных проблем. URL: www.sisp.nkras.ru. [Дата звернення 09.11.2020].

Д. С. Лихачёв об экологии природы и экологии культуры (2017). Круглый стол. URL: libnvkz.ru > news > 28.11.2017-3. [Дата звернення 09.11.2020].

Енииклопедія Сучасної України (2009). URL: esu.com.ua > search_articles. [Дата звернення 09.11.2020].

Концепція екологічної освіти України. (2002) Інформаційний збірник Міністерства освіти і науки Украӥни. 7. СС. 3-23.

Крисаченко, В. (1996). Екологічна культура: теорія і практика. Київ: Заповіт. 352 с.

Курняк, Л. (2015). Екологічна культура: поняття та формування. В: Збірник наукових праць Хмельницького інституту соиіальних технологій «Украӥна». 10. СС. 48-51.

Лещинская, В. (2014). Экологическая культура: несколько шагов к пониманию понятия: Лига культуры. 4. СС. 168-171.

Лисаковский, И. (2002). Художественная культура: Термины. Понятия. Значения: словарь-справочник. М.: РАГС. 240 с.

Лихачов, Д. (1984). Экология культуры. URL: philologist.livejournal.com. [Дата звернення 09.11.2020].

Льовочкіна, А. (2013). Підходи до визначення поняття «екологічна культура». В: Актуальні проблеми психології: Збірник наукових праць Інституту психологї імені Г.С. Костюка НАПН Украӥни. 34. СС. 102-111.

Мухамедишина, Л. (2012). О сущности содержания понятия «экологическая культура». Начальная школа: плюс До и После. 1. СС. 8387.

Пустовіт Г. П. (2002). Екологічне виховання учнів початкових класів у позашкільних навчальних закладах: навч.-метод. посіб. К.: АПН України. $356 \mathrm{c}$.

Устюгова, Е. (2013). Экология культуры: грани проблемы. Вестник СПбГУ. 17/3. СС.64-69. 


\section{Інноватика у вихованні. Випуск 13.Том 1. 2021.}

Holden, J. (2015). The Ecology of Culture. A Report commissioned by the Arts and Humanities Research Council's Cultural Value Project Published by Arts and Humanities Research Council. Swindon, Wiltshire. 43 p. URL: www.ahrc.ac.uk. [Дата звернення 09.11.2020].

Steward, J. H. (1955). Theory of Culture Change: The Methodology of Multilinear Evolution: University of Illinois Press. URL: sites.google.com.EPDF. [Дата звернення 09.11.2020].

\section{REFERENCES}

Vasiukova, H., Hrosheva, O. (2009). Ekolohiia: pidruchnyk [Ecology: textbook]. Kyiv: Kondor. 524 s. [in Ukrainian].

Genisaretskiy, O. (1991). Ekologiya kultury. Teoreticheskiye y proektnyie problemy [Ecology of culture. Theoretical and design problems]. M. $153 \mathrm{~s}$. [in Russian].

Doroshko, O. (2012). Sovremennyie podkhody $k$ opredelenyiu poniatiya „ekologicheskaya kultura”. Sovremennye issledovaniya sotsyalnykh problem [Modern approaches to the definition of the concept of „ecological culture”. Contemporary research on social problems]. URL: www.sisp.nkras.ru. . [Data zvernennia 09.11.2020]. [in Russian].

D. S. Likhachev ob ekologii prirody i ekologii kultury [D.S.Likhachev on the ecology of nature and ecology of culture] (2017). Kruglyi stol. URL: libnvkz.ru > news > 28.11.2017-3. . [Data zvernennia 09.11.2020]. [in Russian].

Entsyklopediia suchasnoi Ukrainy [Encyclopedia of Modern Ukraine] (2009). URL: esu.com.ua > search_articles. [Data zvernennia 09.11.2020]. [in Ukrainian].

Kontseptsiia ekolohichnoi osvity Ukrainy [The concept of environmental education in Ukraine]. (2002) Informatsiinyi zbirnyk Ministerstva osvity i nauky Ukrainy. 7. s. 3-23. [in Ukrainian].

Krysachenko, V. (1996). Ekolohichna kultura: teoriia $i$ praktyka [Ecological culture: theory and practice]. Kyiv: Zapovit. 352 s. [in Ukrainian].

Kurniak, L. (2015). Ekolohichna kultura: poniattia ta formuvannia [Ecological culture: concepts and formation]. Zbirnyk naukovykh prats Khmelnytskoho instytutu sotsialnykh tekhnolohii ,,Ukraina”. 10. SS. 48-51. [in Ukrainian].

Leshchynskaya, V. (2014). Ekologicheskaya kultura: neskolko shahov $k$ ponimaniyu poniatiya: Liga kultury [Environmental culture: a few steps towards understanding the concept: League of Culture]. 4. SS. 168-171. [in Russian].

Lysakovskiy, Y. (2002). Khudozhestvennaya kultura: Termyny. Poniatiya. Znacheniya: slovar-spravochnyk [Art Culture: Terms. Concepts. Values: dictionary-reference]. Moskva: RAHS. 240 s. [in Russian].

Likhachov, D. (1984). Ekologiya kultury [Ecology of culture]. URL: philologist.livejournal.com. [in Russian].

Lovochkina, A. (2013). Pidkhody do vyznachennia poniattia «ekolohichna kultura» [Approaches to the definition of „ecological culture”]. V: Aktualni 
problemy psykholohii: Zbirnyk naukovykh prats Instytutu psykholohii imeni H.S. Kostiuka NAPN Ukrainy. 34. s. 102-111. [in Ukrainian].

Mukhamedishyna, L. (2012). O sushchnosti soderzhaniya poniatiya „ekologicheskaya kultura" [On the essence of the content of the concept of „ecological culture"]. Nachalnaia shkola: plius Do i Posle. 1. s. 83-87. [in Russian].

Pustovit H. P. (2002). Ekolohichne vykhovannia uchniv pochatkovykh klasiv $u$ pozashkilnykh navchalnykh zakladakh: navch.-metod. posib. [Ecological education of primary school students in out-of-school educational institutions: textbook] Kyiv: APN Ukrainy. 356 s. [in Ukrainian].

Ustyugova, E. (2013). Ekologiya kultury: grani problemy [Ecology of culture: facets of the problem]. Vestnik SPbHU. 17/3. SS.64-69. [in Russian].

Holden, J. (2015). The Ecology of Culture. A Report commissioned by the Arts and Humanities Research Councils Cultural Value Project Published by Arts and Humanities Research Council. Swindon, Wiltshire. 43 r. URL: www.ahrc.ac.uk. [Data zvernennia 09.12.2020].

Steward, J. H. (1955). Theory of Culture Change: The Methodology of Multilinear Evolution: University of Illinois Press. URL : sites.google.com.EPDF. [Data zvernennia 09.12.2020].

\title{
THE CONCEPTS "ECOLOGICAL CULTURE", "ECOLOGY OF CULTURE", "CULTURAL ECOLOGY" IN THE CONTEXT OF POSTRADIAN TERMINOLOGICAL DISCOURSE
}

\author{
Borys Savchuk \\ Doctor of Sciences (in History), Professor, \\ Professor at the Bogdan Stuparik Department of Pedagogy \\ Vasyl Stefanyk Precarpathian National University, \\ Ivano-Frankivsk, Ukraine \\ ORCID: 0000-0003-2256-0845 \\ e-mail: boris_savchuk@ukr.net \\ Khrystyna Shevchuk \\ student of the second (master's) level of education \\ at the the Bogdan Stuparik Department of Pedagogy \\ Vasyl Stefanyk Precarpathian National University, \\ Ivano-Frankivsk, Ukraine \\ ORCID : 0000-0002-0034-5143 \\ e-mail: roshniv.ch@gmail.com
}

\begin{abstract}
The article presents the results of the synthesized analysis of the genesis and essence of the concepts "ecological culture", "ecology of culture", "cultural ecology". In the context of postradian scientific discourse, the definitions of their definitive contours and content were considered. Approaches to the interpretation of these terms and their use in scientific research were proposed.
\end{abstract}




\section{Інноватика у вихованні. Випуск 13.Том 1. 2021.}

It is shown that the position has been established in Soviet and modern Russian science, according to which the introduction of the concepts of "ecological culture", "ecology of culture" into scientific circulation is associated with the name of the famous philologist and culturologist D. Likhachev. The position of modern Ukrainian scientists is presented, according to which the origin of the term "ecological culture" was connected with the works of the representatives of the American school of cultural ecology, which existed in the 1920s. The author's position is proved, according to which the term "cultural ecology" was introduced into scientific circulation in 1955 by the American anthropologist J. Steward (Julian Steward). A comparison of views and interpretations of these concepts in the works of D. Likhachev and J. Steward was made.

Based on the analysis of an array of thematic representative studies, common and different approaches to the use and interpretation of the terms "ecological culture", "ecology of culture", "cultural ecology" in different fields of knowledge, in subject-thematic scientific and pedagogical research, in modern Ukrainian and Russian science and English-speaking scientific space, are shown.

It is shown that the priority educational vector caused the most objective study of the phenomenon of ecological culture in the field of pedagogy, the architecture of its reception in the pedagogical science of Ukraine is reconstructed.

Keywords: methodology of pedagogical science, scientific and pedagogical discourse, conceptual and categorical apparatus, ecological culture, ecology of culture, cultural ecology.

Стаття надійшла до редакиії 01.03.2021p. 